\title{
A Regulatory Model to Fight Covid-19 Plague Attack
}

\author{
Rachmat Trijono ${ }^{1 *}$, Muhar Junef ${ }^{1}$, Jamilus ${ }^{1}$, Diana Yusyanti ${ }^{1}$, Indah Harlina ${ }^{2}$, \\ Damrah Mamang ${ }^{3}$, Danu Suryani ${ }^{4}$
}

\author{
${ }^{1}$ Ministry of Law and Human Rights \\ ${ }^{2}$ Faculty of Law Pancasila University \\ ${ }^{3}$ Faculty of Law As-syfi'iyah Islamic University \\ ${ }^{4}$ Faculty of Law Djuanda Univerity \\ *Corresponding author. Email: lkpi.179@gmail.com
}

\begin{abstract}
Regulations to fight plague attacks can be identified to have specific characters. This character forms a specific model. The regulations for dealing with plague are numerous. Specifics character of the regulations for fighting the plague attack is first, all of the regulations were directed to fight the plague. Second, it is made quickly. Third, it is made to complete the emptiness of plague regulation. This research is important to do to find a model for preventing the spread of the Covid-19 plague. The research question is how the 'regulatory model for fighting plague'? The regulations for dealing with plague describing as a 'plague regulatory model' is the theory as a result of this research. The regulatory model found in this study is obtained in the form of the 'tree regulation model'. The 1945 Constitution is the root of the regulation tree. Law Number 4 of 1984 is the basic law as stem regulation. Law Number 6 of 2018 and Law Number 2 of 2020 as the bough regulation, and then another form of regulation as the small-branch regulation. The leaf is the content of the regulation. This research used a qualitative method, with a grounded approach, which is based on document data in the form of statutory regulations. The result of this research is the 'tree-regulation model'. This model is the form of a regulatory model for fighting the plague attack. The purpose of this model is to eliminate disease outbreaks, especially at this time the Covid-19 outbreak, while the benefit of this model is to be used in creating new laws against disease outbreaks quickly, not only covid-19 but also other disease outbreaks, such as diarrhea, smallpox. Research suggests is the 'tree-regulation model' can be used as a hypothesis for other researchers to verify.
\end{abstract}

Keywords: Plague Regulations, Grounded Approach, Tree-Regulation Model.

\section{INTRODUCTION}

The State of Indonesia shall be a state based on the rule of law[1]. It means that practics of the nation, state, and society must be based on the rule of law, including dealing with a plague outbreak.

According to Fischer[2] that an outbreak is an increase in the number of cases seen, albeit small, when compared to the anticipated "normal" number. Imagine a sudden increase in the number of young children with diarrhea visiting a daycare center. One or two sick children may be normal on a typical day, but if 15 children suffer from diarrhea at the same time, this means an epidemic. When a new disease emerges, the outbreak does become more obvious because the anticipated number of cases due to the disease is still empty. According to Sugono[3], the attack is assault. Thus a plague attack is an attack from a disease outbreak

Historically, plague management regulations had been issued since the colonial time. Quarantine regulations were issued in 1911 and loaded in the Staatsblad van Nederlandsch Indie number 277. This regulation gives authority to government officials to do quarantine against certain areas that are otherwise affected by the epidemic of a disease. The goal is to avoid the transmission and spread of disease to other people and the region [4]. Staatsblad Number 723 of 1920 regulates the Public Health Service (Burgerlijk Gezondheid 
Toestand), Chief Port (Haven Meester), and skipper ship (Gezaghebber)[4].

Since Indonesia declared independence on 17 August 1945 has had many regulations to deal with plague outbreak. The 1945 Constitution of the Republic of Indonesia is the highest regulation[1]. In 1984 has had enacted Law Number 4 concerning the Outbreak of Infectious Diseases[5]. In 2018 has had enacted Law Number 6 concerning Health Quarantine[6].

Nowadays, Indonesia and the country all over the world are attacked by Covid-19. As a state based on the rule of law, As a state based on the rule of the law, Indonesia must deal with and prevent Coronavirus 2019 (Covid-19) breakout through the rules. In 2020 has had enacted Law Number 2 concerning the Stipulation of Government Regulation in Lieu of Law Number 1 of 2020 concerning State Financial Policy and Financial System Stability for Handling the Corona Virus Disease 2019(Covid-19) Pandemic and/or in the Context of Facing Threats Endanger the National Economy and/or Stability Financial System Becomes Law[5].

Many regulations of the Republic of Indonesia have been the enactment for dealing with the Covid-19 outbreak. At least 60 of the regulation have been enactment to dealing with Covid-19[4].

Until now, no one the regulatory model for dealing with disease outbreaks, including the prevention and prevention of Covid-19. For that, we conduct research using statutory data which is visualized into a model. The regulatory model for dealing with disease outbreaks is different from other regulatory models. The criminal regulations stipulated in the Criminal Code, for example, form another model. For this reason, it is necessary to find a model to prevent the spread of the Covid-19 outbreak.

\section{RESEARCH METHOD}

The aim of this research is theory-building. This research does not start from a theory or to test a theory (such as a quantitative research paradigm), but rather from data to theory[7].

This research used qualitative methods and a grounded approach[8]. According to Strauss and Corbin that Qualitative research means any kind of research that procedure findings are not arrived at using statistical procedures or other means of quantifications. It can refer to research about persons' lives, stories, behaviors, but also about organizations. Functioning, social covenants, or intellectual relationship[7].

The grounded approach is inductively derived from the study of the phenomenon it represents. It is discovered, developed, and provisionally verified through systematic data collection, analysis of data about that phenomenon. Therefore, data collection, analysis, and theory stand in a reciprocal relationship with each other. One does not begin with a theory, then prove it. Rather one begins with an area of study and what is relevant to that area as allowed to emerge[8].

The collecting instrument used was the researcher himself[9]. The data collected is in the form of public documents, namely laws and regulations, books, and journals[8]. Sampling is done by researchers by selecting data or concepts that are proven to be related to and theoretically support the theory being compiled[8].

The elements of the Grounded method in this research is:

1. not start from a theory;

2. The research base on data;

3. Theory building;

4. This research used qualitative methods, so the data analyzed qualitative method

\section{FINDINGS AND DISCUSSION}

\subsection{Findings}

Grounded research builds a theory. The result of this research is a theory, namely a 'tree regulation model'. It is called a 'tree regulation model', because it is like a tree consisting of roots, stems, twigs and leaves. This is shown in the following figure: 


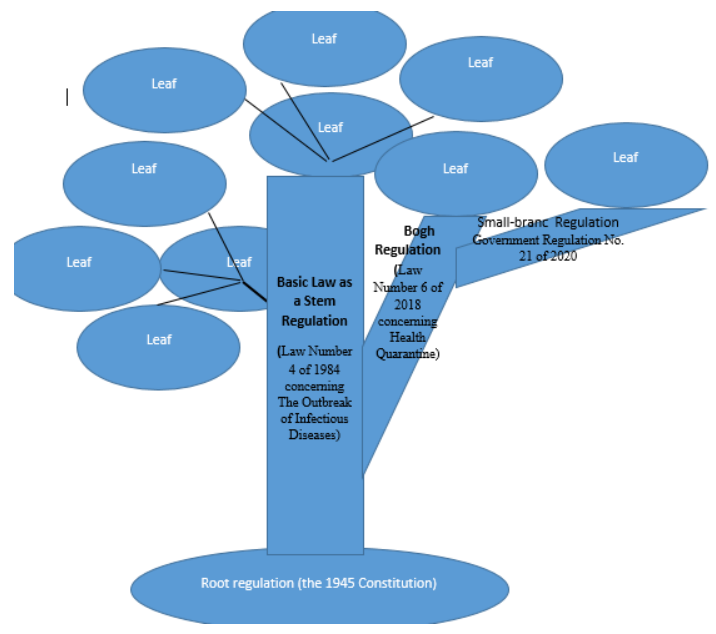

Figure 1 the 'Tree Regulation Model'

The image above shows a regulatory model obtained in the form of the 'tree regulation model'. The 1945 Constitution is the root of the regulation tree. Law Number 4 of 1984 is the basic law as stem regulation. Law Number 6 of 2018 and Law Number 2 of 2020 as the bough regulation, and then another form of regulation as the small-branch regulation. The leaf is the content of the regulation.

\subsection{Discussion}

\subsubsection{Model}

The lexical definition of the model according to Kamus Bahasa Indonesia, the model is the pattern of something[3]. According to MerriamWebster that the meaning of a model is a description or analogy used to help visualize something (such as an atom) that cannot be directly observed[10].

There are at least four types of models, namely[11]:

a. Conceptual Models are qualitative models that help highlight important connections in realworld systems and processes. They are used as a first step in the development of more complex models. People receive information, process this information, and respond accordingly many times each day. This sort of processing of information is essentially a conceptual model (or mental model) of how things in our surrounding environment work[12].

b. Interactive demonstrations are physical models of systems that can be easily observed and manipulated and which have characteristics similar to key features of more complex systems in the real world. These models can help bridge the gap between conceptual models and models of more complex real-world systems[13].

c. Mathematical and Statistical Models involve solving relevant equation(s) of a system or characterizing a system based upon its statistical parameters such as mean, mode, variance, or regression coefficients. Mathematical models include Analytical models and Numerical Models. Statistical models are useful in helping identify patterns and underlying relationships between data sets[14].

d. Teaching with Visualization. By this, we mean anything that can help one visualize how a system works. A visualization model can be a direct link between data and some graphic or image output or can be linked in series with some other type of model so to convert its output into a visually useful format. Examples include 1-, 2-, and 3-D graphics packages, map overlays, animations, image manipulation, and image analysis[15].

All the data in this study visualize the regulatory system that forms the model.

\subsubsection{Regulatory Data}

\subsubsection{Types of Rules}

\subsection{Constitution}

The Constitution of the Republic of Indonesia is the basic law in-laws and regulations [16]. The nature of the 1945 Constitution is simple because it contains basic rules, only contain rules regarding the practice of the state in general. So not all the main issues had been regulated in the 1945 Constitution. Society had been developing, and new issues arise. This then needs to be regulated by law.

\subsection{Law}

Law is legislation formed by the House of Representatives with the joint approval of the President [16].

In Indonesia, there are several meanings of law (wet in Dutch) as follows:

- $\quad$ Law in the material sense (wet in materiele zin) namely legislation formed by the House of 
Representatives with the joint approval of the President which has general binding power and externally effective.

- Law in the formal sense (wet in formele zin) namely legislation formed by the House of Representatives with the joint approval of the President which shows formality of the formation of law

- Basic Law formulated the basics for state administration in certain fields and contain only the main provision. Law Number 5 of 1960 concerning the Basic Agrarian Law[17] is one example. In this research, we use Law Number 4 of 1984[5] as a basic law although the title of the law does not mention 'the basic law.

- Organic law namely legislation formed by the House of Representatives with the joint approval of the President which regulates the material or issues that are outlined by the legal provision on which they are based on the 1945 constitution or basic law. For example, the law on the State Budget and Revenue (APBN) is an organic law that implements the provision of Article 23 Paragraph (1) of the 1945 Constitution.

- Non-organic law namely legislation formed by the House of Representatives with the joint approval of the President which regulates matter that is not explicitly determined by the 1945 Constitution.

- Constitution or the basic law.

\subsection{Government Regulation In Lieu of Law}

Government Regulation In Lieu of Law is the Rules set by the President In case of urgency. This rule has the same function as the law. This type of rule is also known as emergency regulation (noodverordening). The Government Regulation In Lieu of Law must be approved by the House of Representatives in the next trial. If it does not get approval in then the rule must be revoked, and if it is approved by the House of Representative, the Government Regulation In Lieu of Law will be pass to be law. The legal basis of the Government Regulation In Lieu of Law is Article 22 of the 1945 Constitution[1]. The condition for issuing the Government Regulation In Lieu of Law is a precarious condition that forces the government to act promptly and appropriately. In this research, we used the Government Regulation In Lieu of Law Number 1 of 2020[18]. The emergency rule mention above is necessary so that the safety of the state can be guaranteed in a critical situation.

\subsection{Government Regulation}

Government Regulation is Rules are set by the President to implement the Law as it should[16]. There is no government regulation without a law on which it is based (geen regulationverordening zonder wet waar op zij steunt). However, to make a Government Regulation does not have to be expressly stated or stated by the law which is the basis, for example with the sentence "henceforth will be regulated by government regulation". If indeed the Government deems it necessary to implement a law with a Government Regulation, the Government can make it, even though the law in question does not state that it will be regulated subsequently by a Government Regulation. So on the government's initiative alone. In this case, there is a discretion for the Government to make it. But even so, the Government Regulation must remain a mere implementing regulation. Not adding or not creating new norms.

\subsection{Presidential Regulation}

Presidential Regulation is the Rules are set by the President to implement the instruction of higher Rules or in the conduct of governmental power[16].

\subsection{Presidential Decree}

There is a difference between Presidential Regulation and Presidential Decree. A decree is a product of the will (wilsvorming) of an authorized official based on statutory provisions. The decree contains a stipulation (beschikking). The decree only applies once (eenmalig), that is, to solve a concrete problem. After the problem that becomes the object of the decree has been resolved, the decision automatically stops working. Meanwhile, the regulations are meant to continue to apply. This research uses Presidential Decree Number 7 of 2020 concerning the Task Force Acceleration of Handling Corona Virus Disease 2019 (Covid-19), Presidential Decree Number 9 of 2020 concerning Change Presidential Decree Number 7 of 2020 About Acceleration Task Force Handling Corona Virus Disease 2019 (Covid-19), Presidential Decree Number 11 of 2020 concerning Determination Health Emergencies Corona Virus Society Disease. 


\subsection{Presidential Instruction}

Instruction is the official direction from the higher official to the lower official. Presidential instruction is the official direction of the President. In this research, we use Presidential Instruction Number 4 of 2020 concerning Activity Refocusing, Budget Relocation, and Procurement of Goods and Services in the Context of Accelerating Handling of Corona Virus Disease 2019 (Covid-19).

\subsection{Ministerial Regulation}

Ministerial regulation is an implementing regulation made by the Minister of the relevant department to regulate matters belonging to the area of his / her authority based on and originating from higher-level legislation.

Based on Article 8 Paragraph (1) of Law Number 12 Year 2011 concerning the Formation of Laws and Regulations[16] in conjunction with Law Number 15 Year 2019[19], Ministerial Regulation is one of the types of laws and regulations in Indonesia.

In this research, we used Regulation of Minister Trading Number 23 of 2020; Regulation of Minister of Law and Human Rights Number 11 of 2020; Regulation of Minister Finance Number 23/PMK.03/2020; Regulation of Minister of Health Number 9 of 2020.

\subsection{Ministerial Decree}

A ministerial decree contains a decision from the Minister concerned who determines something in the framework of implementing the higher level legislative provisions. In this research, we used Ministerial Decree of Health Number 612/MENKES/SK/V/2010 concerning Guidelines Implementation of Quarantine Health On Countermeasures Health Emergencies Yang society Troubling the World, Ministerial Decree of Health Number HK.01.07/ MENKES/169/2020 concerning House Designation Emerging Infection Pain Certain.

3.2.2.1.10. $\begin{aligned} & \text { Regulation of The Chairman of } \\ & \text { Non-Ministry } \\ & \text { Institutions }\end{aligned}$
Government

Regulation of the Chairman of Non-Ministry Government Institutions is the implementing regulation of higher-level legislation or implementation of the policies outlined by the President in the field of non-departmental government institutions and not one of the ministry. In this study, we use OJK Regulation Number: 11/POJK.03 / 2020

\subsection{Circular Letter}

Circular here is one that contains regulatory material. Inthis study, we use Circular letter Head of BNPB Number: SE-1/BNPB / 03/2020 concerning Formation Acceleration Task Force Handling Covid-19 Provincial-level and Regency/City, Circular letter Minister of Health Number: HK.02.02 / III / 375/2020 about Use of the Booth In-Order Disinfection Prevention of Transmissionn Covid-19, Circular letter Menpan RB Number 19 of 2020 About Customization Civil Apparatus Work System Country In Effort Prevention of the Spread of Covid-19 in the Environment Government agencies, Circular letter Menpan RB Number 36 of 2020 About Restrictions Activities Traveling to Outside the area and or Homecoming Activities State Civil Apparatus In preventive efforts The spread of Covid-19, Circular letter Minister of Education and Culture Number 3 of 2020 About Prevention Corona Virus Diseases (Covid-19) In Unit Education, Corruption Eradication Commission Circular Number 8 of 2020 About Usage Goods / Services Procurement Implementation Budget In Acceleration Order Handling Corona Virus Disease 2019 (Covid 19) Associated with Crime Prevention Corruption, Circular letter Ministry of Manpower Number: M/3/HK.04 /III/2020 About Protection Workers / Laborers and Business Continuity In the Framework of Prevention And countermeasures Covid-19, Circular letter Head of BKN Number: 10/SE/IV/2020 About Dan's Inauguration Taking Oath/Promise PNS Or Oath/Promise Position Through the Media Electronics / Teleconference During the Status of a Certain Disaster Emergency Resultant Disease Outbreaks Corona virus, Circular letter Minister of Home Affairs Number: 440/2622/SJ About Establishment Acceleration Task Force Handling Covid-19 Area

\subsection{Fatwa}

Fatwa is an official statement or order from an Islamic religious leader. In this research, we use MUI Fatwa Number 14 of 2020 concerning the 
Implementation of Worship in a Situation of the Covid-19 Outbreak

\subsubsection{The System of Regulation}

The legislation is the rule written containing binding legal norms in general and established or determined by state institutions or authorized officials through procedures stipulated in the Regulations Legislation[16]. The legislation is made by authorized officials or institutions [16].

Types and hierarchy of Rules consist of [16]:

a. Constitution of the Republic of Indonesia of 1945;

b. People's Consultative Council Decree;

c. Law/Government Regulation In Lieu of Law;

d. Government Regulation;

e. Presidential Regulation;

f. Province Regulation; and

g. Regency/Municipality Regulation.

Another type of regulation according to Article 8 Paragraph (1) covers the regulations stipulated by the People's Consultative Agency, House of Representatives, Regional Representatives Council, the Supreme Court, the Constitutional Court, the State Audit Board, the Judicial Commission, Bank of Indonesia, the Minister, agency, institution, or same level commission established by Law or Government on the instruction of Law, Provincial Regional House of Representatives, Governor, Regency/Municipality Regional House of Representatives, Regent/Municipal Government, the Village Head or the equivalent.

Based on existing research data, they are grouped in the table below:

Table 1

\section{Tree Regulation Model}

\begin{tabular}{|c|c|c|c|}
\hline $\begin{array}{l}\text { Root } \\
\text { Regulation }\end{array}$ & $\begin{array}{l}\text { Stem } \\
\text { Regulation } \\
\text { (Basic-Rule) }\end{array}$ & $\begin{array}{l}\text { Bough } \\
\text { Regulations }\end{array}$ & $\begin{array}{l}\text { Small- } \\
\text { branch } \\
\text { Regulation }\end{array}$ \\
\hline $\begin{array}{l}\text { The } 1945 \\
\text { Constitutio } \\
\text { n }\end{array}$ & $\begin{array}{l}\text { Law Number } \\
4 \text { of } 1984 \\
\text { concerning } \\
\text { The } \\
\text { Outbreak of } \\
\text { Infectious } \\
\text { Diseases }\end{array}$ & $\begin{array}{l}\text { Law Number } 6 \\
\text { of } 2018 \\
\text { concerning } \\
\text { Health } \\
\text { Quarantine, } \\
\text { Law Number } 2 \\
\text { of } 2020\end{array}$ & $\begin{array}{l}\text { Government } \\
\text { Regulation, } \\
\text { Presidential } \\
\text { Decree, } \\
\text { Presidential } \\
\text { Instruction, } \\
\text { Ministerial } \\
\text { Regulation, }\end{array}$ \\
\hline
\end{tabular}

\begin{tabular}{|l|l|l|l|}
\hline & concerning the & Presidential \\
& Stipulation of & Regulation, \\
& Government & Presidential \\
& Regulation in & Instruction, \\
& Lieu of Law & Ministerial \\
& Number 1 of & Regulation, \\
& 2020 & Ministerial \\
& concerning & Decree, \\
& State Financial & Circular \\
& Policy and & Letter, and \\
& Financial & Fatwa. \\
& System & \\
& Stability for & \\
& Handling the & \\
& Corona Virus & \\
& Disease 2019 & \\
& (Covid-19) & \\
& Pandemic & \\
and/or in the & \\
& Context of & \\
& Facing Threats & \\
& Endanger the & \\
& National & \\
& Economy & \\
& and/or Stability & \\
& Financial & \\
& System & \\
& Becomes Law. & \\
& & \\
& & \\
& & \\
& & \\
& & \\
& & \\
& &
\end{tabular}

\subsubsection{Characteristic of the regulation}

1. Characteristic of the regulation as a root described as follow:

a) Regulated in the 1945 Constitution.

b) The 1945 Constitution is the Indonesian highest regulation.

2. Characteristic of the regulation as a stem regulation describes as follow:

a) Regulated in the Law;

b) In the form of 'the Basic Law' (UndangUndang Pokok').

c) The basic law that regulates only the main point.

d) although the title of the law does not mention 'the basic-law'.

e) The sum of the basic law is just one.

This research finds that Law Number 4 of 1984 concerning The Outbreak of Infectious Diseases is the basic law. The basic law is a law the principle 
or principle in regulating something and still requires implementing regulations.

The main point of the basic law describes in Article 5 Paragraph (10) Law Number 4 of 1984. This article is flexible, because:

a. contains only the main points;

b. can be followed up with other regulations under the law.

Article 5 Paragraph (10) Law Number 4 of 1984 which state that Plague prevention efforts include:

a. epidemiological investigations;

b. examination, treatment, care, and isolation of the patient, including patients quarantine;

c. prevention and immunization;

d. elimination of diseases causes;

e. handling of the body due to the plague;

f. outreach to the community;

g. other countermeasures.

The basic law is further elaborated into the law which regulates the points in the basic law. In this research, the law that elaborates on basic law is Law Number 6 of 2018 concerning Health Quarantine, Law Number 2 of 2002 concerning the Stipulation of Government Regulation in Lieu of Law Number 1 of 2020 concerning State Financial Policy and Financial System Stability for Handling the Corona Virus Disease 2019 (Covid-19) Pandemic and/or in the Context of Facing Threats Endanger the National Economy and/or Stability Financial System Becomes Law.

Further, elaborate by Government Regulation, Presidential Regulation, and another regulation form.

\section{CONCLUSION}

Based on the discussion above, it is clear that this study finds a theory of the regulatory system, namely the 'tree regulation model'. The power of the 'tree regulation model' is the basic law (UndangUndang Pokok), and the sum of the basic law just one. After forming the basic rules, the regulator makes rules that complement the basic rules, namely 'bough regulations' which form of law, then makes other rules form as a Small-branch Regulation.
This model can be used by the regulator for making law, Government Regulation in Lieu of Law, Government Regulation, Presidential Decree, Minister Decree, and another regulation form. Academically, the 'tree-regulation model' can be used as a hypothesis for other researchers to verify with the same data and method.

The advantage of this model is that it can be used to form laws and regulations, in one particular group, namely in the 'main law' group, while the disadvantage of this model is that there must be a 'main law' first.

\section{REFERENCES}

[1] Indonesia, "The 1945 Constitution of the Republic of Indonesia," Journal of CrossCultural Psychology. 1945.

[2] R. S. B. Fischer, "Apa bedanya pandemi." Texas A\&M University, Texas, 2020.

[3] D. Sugono, Kamus Bahasa Indonesia. Jakarta, 2008.

[4] S. POLRI, "Kumpulan Peraturan dan Pedoman Penanganan Virus Corona Disease (COVID19).” 2020

[5] Indonesia, "Undang Undang Nomor 4Tahun 1984 tentang Wabah Penyakit Melular." 1984.

[6] Indonesia, "UU Nomor 6 tahun 2018 tentang Kekarantinaan Wilayah," pp. 3134, 2018.

[7] J. M. C. Anselm L. Strauss, Basics of Qualitative Research: Techniques and Procedures for Developing Grounded Theory. California: SAGE Publication, Inc., 1998.

[8] John W. Creswell, Educational Research. Boston: Pearson, 2012.

[9] P. Michael Quinn, Qualitative Research \& Evaluation Methods. London: Sage Publication, 2002.

[10] Merriam-Webster, "Model.” 2020.

[11] J. N. R. Jeffers and J. N. R. Jeffers, "What is a model?," Modelling. pp. 7-13, 1982.

[12] C. C. Bob MacKay, "What Are Conceptual Models?"p. 2013.

[13] D. Pritchard, "Interactive Lecture Demonstrations," Science. pp. 1-10, 2002. 
[14] A. S. C. Ehrenberg, "Mathematics and statistics," Journal of Applied Statistics, vol. 2, no. 2. pp. 1-6, 1975.

[15] C. C. Bob MacKay, "Teaching with Visualizations.”.

[16] Indonesia, "Undang-Undang Republik Indonesia Nomor 12 Tahun 2011 tentang Pembentukan Peraturan PerundangUndangan," 2011.

[17] Indonesia, "Undang-Undang No.5 Tahun1960 Tentang Pokok-Pokok Dasar Agraria [Law No.5/1960 Concerning Basic Regulation on Agrarian Principles]," no. 5, 1960.

[18] Indonesia, "Peraturan Pemerintah Pengganti Undang-Undang Republik Indonesia Nomor 1 Tahun 2020 tentang Kebijakan Keuangan Negara dan Stabilitas Sistem Keuangan Untuk Penanganan Pandemi Covid-19 dan/atau Dalam Rangka Menghadapi Ancaman Yang Membahayakan Perekonomian N." 2020.

[19] Indonesia, "Undang-Undang Republik Indonesia Nomor 15 Tahun 2019 tentang Perubahan Atas Undang-Undang Nomor 12 Tahun 2011 tentang Pembentukan Peraturan Perundang-Undangan,” 2019. 